The effect of metacognitive instruction on improving listening comprehension ability of intermediate EFL learners

Latifi, Mehdi $\bowtie$

University of Isfahan, Iran (Smm_latifi@yahoo.com)

Tavakoli, Mansoor

University of Isfahan, Iran (Mr.tavakoli@gmail.com)

Dabaghi, Azizollah

University of Isfahan, Iran (dabaghi@ui.ac.ir)

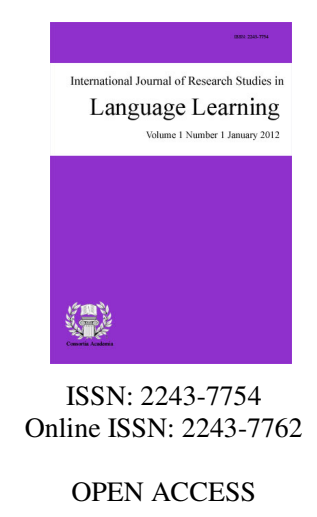

Received: 24 December 2013

Revised: 24 February 2014

Available Online: 16 March 2014

\title{
Abstract
}

The present study investigated the effectiveness of metacognitive instruction on the improvement of listening comprehension ability of EFL learners. Sixty EFL Persian-speaking constituted the groups; a High Skilled Group (HSG), a Less Skilled Group (LSG), and a Control Group (CG). The results of the posttest indicated that there was a significant difference between all groups, and that the treatment was considerably effective. The High and Less Skilled groups outperformed the other group being the Control Group, on the posttest. Besides, although there was no significant difference between the High and Less Skilled learners on the post test, the Less Skilled learners had the most significant improvement by considering their pretest results and the extent to which they managed to improve. The findings of the study led us to conclude that Less Skilled learners make a noticeable progress via metacognitive instruction. It should also be noted that the intervention resulted in a significant improvement for the High skilled learners as well, but to a lesser extent.

Keywords: high skilled listeners; less skilled listeners; listening comprehension; metacognitive instruction 


\section{The effect of metacognitive instruction on improving listening comprehension ability of intermediate EFL learners}

\section{Introduction}

Those who have learned a foreign language may have the feeling of not being capable of communicating with native speakers of the language, in spite of developing their skills. Sometimes, learners are good at visual comprehension, yet some others may fail to identify them in a spoken utterance. The main reason why this communication problem occurs is the lack of ability among listeners to recognize the words in the pace in which they are spoken. To put it simply, listeners may have a good number of lexicon, but they may have difficulty using it at a specific time (Vandergrift, 2003).

Another phenomenon known by many learners of a foreign language is finding what to say and how to say it before or after a conversation but not during the conversation itself. Again, language learners may have enough vocabulary and grammar knowledge to construct correct sentences in reply to what an interlocutor has just said but they may not be able to access and retrieve the language elements from their mental lexicon fast enough. The two situations sketched above indicate that there is a difference between using a language with and without time constraints. Apparently, language learners often suffer from their disability in accessing their knowledge (e.g., vocabulary, grammar, and pronunciation) in a fluent (i.e., fast and accurate) way. It has been demonstrated that successful communications can have profound effects on the fluency. But on the other hand, acquisition of language knowledge not the automatisation of knowledge has been the focus for foreign-language courses (Goh, 2008).

Summarizing the process of language learning into knowledge use can cause foreign language users to lose their fluency, and then expecting them to reach a near-native language level is beyond the realm of possibility. The paramount importance of using a language correctly would be best realized in today's world in which international communications have been emphasized. For instance, learning the language spoken by Dutch quickly and effectively is indispensible for those who emigrate to Netherland, since it is significant for the immigrants to learn the official language spoken in the host country (Oxford, 2011). The importance of conducting research for developing the best method for learning a foreign language has always been emphasized. Listening, in particular, as an important factor in communication needs to be taken into consideration in different studies.

Only after the early 1900s, has listening been believed to have a leading role in language teaching. No sooner had anthropologists started to describe the spoken languages of the world than attention was drawn towards speech perception. The spirit of the times is expressed by Leonard Bloomfield (1942, as cited in Rost, 2002): 'one learns to understand and speak a language primarily by hearing and imitating native speakers'. In spite of the fact that listening plays important roles in language acquisition, it is surprising that it was not treated as a distinct part of language curriculum until the 1970s (Rost, 2001).

\subsection{How to Teach Listening Comprehension}

More recently, there has been a move from non-teaching of listening in the Audio-Lingual period (They will pick it up by exposure), to unplanned listening to texts (many being readings of written languages) followed by comprehension questions, to a 'strategy-based approach'. This means that they are being taught how to listen (Mendelsohn, 1994). In the course of time, the traditional way of teaching listening has given way to listening comprehension strategies (Vandergrift, 2002). What is normally expected from learners in most language courses, the recognition of one of the first steps of listening i.e. words and phonemes and the message, in general, has been given less attention. It has been recommended by some specialists that processing speech efficiently 
The effect of metacognitive instruction on improving listening comprehension ability

requires an emphasis on lower-order processes of the listening skill and familiarity with the features of the spoken language (Mendelsohn, 1994).

On the other hand, some scholars proposed the idea that such a low-order approach cannot be effective. Buck (2001) for example, states that the 'pre-communicative practice' (i.e., sound discrimination, recognizing reduction, assimilation, word boundary distortion) is a 'necessary but insufficient condition for success'. In brief, it can be stated that on the one hand, emphasizing lower-order processes like the recognition of sounds and words turn out to be useful, but on the other hand, the impact of such an approach is still unclear and needs to be complemented by other approaches.

In the past, only the product of listening was considered as the ultimate goal of language teachers and evaluations were based on the exactness of the responses that students would provide to the answers. The mental and psychological processes that learners would go through were completely discarded (Vandergrift, 2007). With the shift of attention in teaching and the prominent role that was given to the process of comprehension, process listening came into focus. Nowadays, a specified amount of time is allocated to teaching listening in second language classes, and it is not viewed as a passive skill anymore. Consequently, attempts were made to improve learners' listening comprehension ability, for instance, via teaching metacognitive strategies (see Omaggion-Hadley, 1986).

\subsection{What is Metacognition and how it helps?}

Simply put, meta-cognition is defined as thinking about thinking and its description comes from cognitive psychology which views meta-cognition as the knowledge of an individual concerning his/her cognitive processes and products. Some basic components of meta-cognition are regarded to be active monitoring, consequent regulation and orchestration of the processes to achieve a goal (Flavell, 1976, as cited in Goh, 2008).

Another description of meta-cognition which is in line with the previously mentioned one is to think of meta-cognitive development as conscious development in one's meta-cognitive abilities. This can include a move to greater knowledge, awareness and control of one's learning, selecting strategies, monitoring the progress of learning, correcting errors, analyzing the effectiveness of learning strategies, and changing learning behaviors and strategies when necessary (Ridley et al., 1992; Wand \& Li, 2014).

According to Anderson (2002) the use of meta-cognitive strategies activates the way the individual thinks and generally leads to enhanced performance in learning. A number of advantages have been listed for learners who have meta-cognitive abilities in contrast to those who are not taking advantage of meta-cognition in learning another language:

$>\quad$ They are more strategic learners.

$>\quad$ Their rate of progress in learning as well as the quality and speed of their cognitive engagement is faster.

$>$ They are confident in their abilities to learn.

$>\quad$ They do not hesitate to obtain help from peers, teachers, or family when needed.

$>\quad$ They provide accurate assessments of why they are successful learners.

$>\quad$ They think clearly about inaccuracies when failure occurs during an activity.

$>\quad$ Their tactics match the learning task and adjustments are made to reflect changing circumstances.

$>\quad$ They perceive themselves as continual learners and can successfully cope with new situations (Wenden, 1999). 
Meta-cognitive strategies, therefore, apply to specific fields such as listening comprehension as well as general fields. Acceding to Vandergrift (1997), meta-cognitive strategies such as analyzing the requirements of a listening task, activating the appropriate listening processes required, making appropriate predictions, monitoring their comprehension and evaluating the success of their approach can be the point of difference between skilled and less skilled listeners. Goh (2008) also provides a list of positive effects for meta-cognitive strategy training in listening comprehension. She believes that these strategies lead to the improvement of the students' confidence and reduce their anxiety during the processing of listening input.

It is believed that Metacognitive instruction will raise students' awareness of their listening and learning processes which, in turn, will develop their capability to apply proper strategies in different contexts (Goh, 2008). Metacognitive instruction has proved to be helpful and of benefit in teaching reading specifically for first language readers (Pressley, 2002; Vaez Dalili \& Tavakoli, 2013). According to Oxford (2011), by having appropriate task knowledge about listening, learners can plan, monitor and evaluate what they want to do. This is completely different from the case where learners start listening without any plans and randomly. This will result in frustration among learners. Even more, Flavell mentions that metacognition can also have some constructive effects on the total ability of students on learning in general:

\begin{abstract}
I believe that metacognitive knowledge can have a number of concrete and important effects on the cognitive enterprises of children and adults. It can lead you to select, evaluate, revise, and abandon cognitive tasks, goals, and strategies in light of their relationships with one another and with your own abilities and interests with respect to that enterprise. Similarly, it can lead to any of a wide variety of metacognitive experiences concerning self, tasks, goals, and strategies, and can also help you interpret the meaning and behavioral implications of these metacognitive experiences (Flavell 1979, p. 908).
\end{abstract}

To capture the effects of the metacognitive instruction, some scholars carried out different studies. Goh and Yusnita (2006), and Nathan (2008), for example, in their studies found that a positive effect was engendered on learners' expansion of metacognitive knowledge for listening comprehension by encouraging young language learners to collaborate while carrying out a listening task. It was also proved in some studies that metacognitive knowledge can be augmented via classroom instruction (Liu \& Goh, 2006; Mareschal, 2007; Vandergift, 2004). Zhang and Goh (2006) produced even more evidence indicating that those listeners who know the potential advantages of metacognitive strategies are more probable to apply such strategies to enhance their listening comprehension ability in communication.

Goh (2000) has also found out that by growing the listeners' knowledge of meta-cognitive strategies, they will be more autonomous in solving their listening problems and that they won't give up the listening task very fast any more. Besides, Vandergrift (2002) in his study found that the exploitation of meta-cognitive strategies (for example, prediction and evaluation) has the capacity of leading listeners to success in L2 listening tasks. According to the findings Vandergrift mentioned that the success achieved in a particular task can be extended to future tasks and that the listeners will learn how autonomously work out more comprehension in their future listening tasks (Vandergrift, 2003). In another study, Vandergrift (2003b) found out that better listeners exploit more meta-cognitive strategies during the listening task compared to the less skilled listeners over the study period. Vandergrift explained that the possible reason behind it can be the fact that less skilled listeners, before the treatment, had a hard time using meta-cognitive strategies as they were dealing with different listening tasks.

Mareschal (2007) also studied the effect of self-regulation and meta-cognitive strategy instruction on some low and high intermediate French language learners during 8 weeks of language training program. The results of data analysis by using a listening questionnaire (MALQ), stimulated-recall protocols, diaries, think-aloud protocols, and a final summative open-ended questionnaire, revealed that the students benefited from the metacognitive strategy instructions and were able to self-regulate themselves better during the listening task; therefore, their listening comprehension ability improved. 
Coskun (2010), in another study, investigated the effect of metacognitive listening strategy training on the listening performance of a group of beginner preparatory school students at a university in Turkey. The experimental group received five weeks of metacognitive strategy training embedded into a listening course book, while the other group did not. At the end of the training, a listening test taken from the teacher's manual of the same course book was administered to both groups. The analysis of the test scores revealed that the experimental group did statistically better on the test.

Finally, Rasouli, Mollakhan, and Karbalaei (2013) examined the effect of metacognitive listening strategies training on EFL learners' listening comprehension. The participants in the study were selected from six intact classes. A listening comprehension test, pre-test and post-test standardized measures of listening comprehension, and metacognitive listening strategy questionnaire were administered to the experimental and control group. Paired-sample T-test was utilized for the purpose of data analysis. The results of this study showed that metacognitive strategy training can advance EFL learners' comprehension ability from the beginning level to a higher level of listening comprehension.

However, the studies which used metacognitive instruction to train good listeners produced inconsistent results. Metacognitive instruction proved to be helpful in many studies such as Graham and Macaro (2008), Vandergrift (2002, 2003, 2004, 2006) and Liu and Goh (2006). While in Ozeki's (2000), and Seo (2000) it was found that metacognitive instruction was not very helpful for L2 learners. Therefore, there is an urge to carry out more research on the role of metacognitive instruction and scrutinize different issues which can play a role in the effectiveness of the metacognitive approach in teaching listening comprehension.

Moreover, all of the above mentioned studies had a major shortcoming which is merely focusing on teaching of individual comprehension strategies, rather than the development of the overall strategic L2 reader (Grabe, 2009). Little attention has been paid to a systematic practice in L2 listening (see DeKeyser, 2007) - that is, on the combined instruction of a group of strategies all together to help L2 learners develop comprehension skills for real-life listening (Vandergrift, 2004). The present study, therefore, tried to exploit a process-based approach to teaching listening that aimed to develop overall strategic L2 listeners and to teach them how to orchestrate the strategies they have at their disposal. Rather than being taught strategies one at a time, listeners should go through the metacognitive processes of listening through the coordinated use of multiple strategies to interpret oral texts. In this way, they will be more efficient learners.

To this end, Vandergrift and Tafaghodtari (2010) conducted one of the few studies which adopted a process based approach. They investigated the effects of a meta-cognitive, process-based approach to teaching second language (L2) listening over a semester. Participants listened to some texts using a methodology that led learners through the meta-cognitive processes (prediction/planning, monitoring, evaluating, and problem solving) underlying successful L2 listening. Development of metacognition about L2 listening, was measured by the Meta-cognitive Awareness Listening Questionnaire (MALQ). The results of data analysis revealed the effectiveness of meta-cognitive strategies. However, as there are few studies addressing this gap so far, an urgent if felt to carry out more process based studies using metacognitive instruction.

\subsection{Significance of the study}

As Oxford (2011) mentioned, most listening classes are merely a test of listening rather than teaching it. Listening classes nowadays are "a conventional listening comprehension lesson that simply add yet another text to the learners' experience; it does little or nothing to improve the effectiveness of their listening, or to address their shortcomings as listeners" (Mareschal, 2007, p. 35). The problems that listeners encounter during the listening task are dealt with in the form of merely translating the problematic parts or writing it up verbatim on the board; however, no attention is paid to teaching the process of listening that is the source of most of listening difficulties. This problem can be addressed via a metacognitive approach to teaching listening comprehension which is majorly neglected. 
In addition, as the context in which strategy instruction is implemented, is of major importance (Oxford \& Cohen, 1992) more studies are required to capture the effectiveness of strategy instruction in different contexts. According to Cohen and Macaro (2007), language researchers must conceptualize strategy instruction in a way that includes the social and affective sides of learning. Therefore, some significance is attached to the present study to look into this issue in another context which is Iran. Besides, there is also a debate as to the relationship between success at learning and strategy deployment, and between proficiency levels and strategy deployment which is the focus of the present study. However, these factors and their possible effects on learners' comprehension have not been investigated sufficiently in the listening research (Cohen \& Macaro, 2007). As a result, the present study is going to address this gap.

\subsection{Research questions and hypotheses}

$>$ What are the effects of meta-cognitive strategy instruction on the listening comprehension achievement of Intermediate English Learners?

$>$ How are the effects of meta-cognitive strategy instruction different, on the Intermediate Less and High skilled English learners?

\subsection{Research Hypotheses}

$>$ There are no effects for meta-cognitive strategy instruction on the listening comprehension achievement of intermediate English learners in Iran.

$>$ There are no differences for meta-cognitive strategy instruction on the Intermediate Less and High skilled English learners.

\section{Methodology}

\subsection{Participants}

Sixty male and female English language learners (out of 359) were selected by means of a listening section of an IELTS test and were assigned into 3 groups. Participants' selection criteria were as follows. The average grade point of all participants was calculated and those who fell in the range of one standard deviation below and above the mean were chosen to be a part of the study. Those who scored more than +.5 to one standard deviation above the mean were considered as high skilled and those who scored more than -.5 to one standard deviation below the mean were assigned into the less skilled group. Then three groups were formed: a High Skilled Group (HSG), a Less Skilled Group (LSG), and a Control Group (CG). The Control Group had a combination of high and less skilled learners. Each group had 15 participants while the Control Group had 30 students to have an equal number of less and high skilled learners like the other groups and even the numbers up in the final data analysis which will be discussed in the following sections. The participants were mostly between the age-range of 16 to 25. They were all selected from Sadr, Basir and Kaj language centers in Isfahan.

\subsection{The Pretest and Posttest}

Two different IELTS listening tests were chosen to be given to the participants at two different points. The first on was given to the participants before the treatment as the pre-test and the second one was used immediately at the end of semester as the post-test to see if the learners could still benefit from the treatment and extend what they have learnt to a different context. The two listening sections of the IELTS test were taken from the IELTS Cambridge books published by Oxford University Press. 


\subsection{The intervention}

Sixty male and female English language learners (out of 359) were selected by means of a Listening section of an IELTS test and were randomly assigned into three groups: a High Skilled Group (HSG), a Less Skilled Group (LSG), and a Control Group (CG). The Control Group had a combination of high and less skilled learners. As for the materials, Ice Age movies (3 and 4) were the focus of listening exercises, for periods of approximately 45 minutes, three times a week during a 10-week semester. The movies were segmented to vary in length from 9 to 11 - minute long.

The students were required to watch their related movies without any preparations due to the fact that the same thing happens in the real life situations (Vandergrift, 2003). Besides, this could help the learners to improve their meta-cognitive awareness. At the outset of this study, the pretest was administered. Then, the normal training was given to the learner which is as follows:

First, before listening to the text, the students were instructed to think about the best possible ways to deal with approaching the listening task (some training was given beforehand). For instance, what kind of self-control and strategic skills may come in useful for successful comprehension? The teacher would model a strategy like how to predict and what comes next. Then for the first listen, the selected part would be played uninterrupted. After that, the students would be required to write down the general points that they had managed to understand, and the factors that their comprehension was based on.

After that the listening text was played for a second time uninterrupted. Similar to the first listen, the students were asked to write down their understanding of the text, how they could understand it, and if there were any changes compared to their first listen and why? Besides, they were asked to mention the points that they wanted to look for or pay attention to in the third listen? Then, the students would discuss, in English or Persian and with their partners, the problems that they had in the understanding of the text, and the ways that they used to resolve their problems. Finally, they would discuss how to approach the third listen.

The text would be played for the third time (uninterrupted). Similar to the previous listens, they would watch the related movies and share their understanding and problems either in Persian or English. They were required to talk about the ways that they solved their problems; than they should have specifically talked about how they tried to make sense of it, and what their idea was about the different techniques that were deployed in this regard. They were then asked to write the useful points which were discussed in the class. In the post listening activities, some strategies would be emphasized on and presented by the teachers as a model. For example;

$>$ Remember to focus attentively throughout the listen

$>$ Remember not to focus excessively on individual segments.

$>$ Resist the temptation to translate literally while listening, to not get discouraged if parts of a text proved difficult to understand,

$>\quad$ Remember to systematically question and double-check any unfamiliar expression which had been guessed, and to draw from a variety of sources of back ground knowledge you have for comprehension.

The same steps were also followed for the control groups, except for the direct and conscious explanations and verbalizations of the strategies. They would watch the movie and discuss them, but no strategy instruction was involved. 


\section{Data Analysis}

\subsection{Pretest}

Table 1

ANOVA for the Mean Comparison of Total Scores between all Groups

\begin{tabular}{llllll}
\hline & Sum of Squares & $d f$ & Mean Square & $F$ & Sig. \\
\hline Between Groups & 5.633 & 2 & 2.817 & 15.339 & .000 \\
Within Groups & 10.467 & 57 & .184 & & \\
Total & 16.100 & 59 & & & \\
\hline
\end{tabular}

A one-way ANOVA was run in order to demonstrate the preexisting differences among the groups on the pretest which showed a level of significance. The results of the pretest have been depicted in Table 1. The results of the ANOVA as displayed in Table 1 show that the groups are significantly different from one another $(F=$ 15.339, $p: 0.000$ ). However, a Scheffe post hoc analysis was conducted in order to identify the direction of differences. The results are demonstrated in Tables 2.

Table 2

Scheffe Post Hoc for ANOVA

\begin{tabular}{lllllll}
\hline & & \multicolumn{2}{l}{ Mean Difference } & \multicolumn{2}{l}{$95 \%$ Confidence Interval } \\
(I) Groups & $(\mathrm{J})$ Groups & (I-J) & Std. Error & Sig. & Lower Bound & Upper Bound \\
\hline High Skilled & $\begin{array}{l}\text { Less Skilled } \\
\text { Learners }\end{array}$ & $.86667^{*}$ & .15647 & .000 & .4734 & 1.2600 \\
& Control Group & $.43333^{*}$ & .13551 & .009 & .0927 & .7739 \\
Less Skilled & High Skilled & $-.86667^{*}$ & .15647 & .000 & -1.2600 & -.4734 \\
& Control Group & $-.43333^{*}$ & .13551 & .009 & -.7739 & -.0927 \\
Control Group & High Skilled & $-.43333^{*}$ & .13551 & .009 & -.7739 & -.0927 \\
& Less Skilled & $.43333^{*}$ & .13551 & .009 & .0927 & .7739 \\
\hline
\end{tabular}

Note. ${ }^{*}$ The mean difference is significant at the 0.05 level

A post hoc pairwise comparison was also conducted to show where the difference could be detected among the groups. The results of the post hoc can be seen in Table 2. The results show that the High Skilled learners did better than the other groups involved in the study, and that High Skilled learners and the Control Group performed significantly different from Less Skilled learners at the probability level of 0.05 . As it can be seen in Table 2, the results of the HS group on the pretest were significantly better than the Less Skilled Group (mean difference $=.86667$, p: 0.000). In addition, even the Control Group learners did better than the Less Skilled Group learners with the mean differences of .433 and $P$ value of 0.009 . The post hoc comparisons also indicated that the CG which came in second in the current experiment did better than the LSG. The differences between the performances of CG compared with the LSG are due to the fact that the CG learners had the combination of both high and less skilled learners.

\subsection{Post Test}

After the analysis of the pretest results, another one-way ANOVA was run to capture the improvement of different groups involved in the study after the treatment. Table 3 shows that there is a significant difference in the scores obtained from all three groups, as the probability value is substantially smaller than the specified critical value $(p=0.000 \& \mathrm{~F}=217.822)$. The results revealed that there was a significant difference among all groups. A Scheffe post hoc was also performed to identify the direction of the differences. The results are demonstrated in Tables 4 and 4. 
The effect of metacognitive instruction on improving listening comprehension ability

Table 3

ANOVA for the Mean Comparison of Total Scores between all Groups

\begin{tabular}{llllll}
\hline & Sum of Squares & $d f$ & Mean Square & $F$ & Sig. \\
\hline Between Groups & 6.092 & 2 & 3.046 & 17.822 & .000 \\
Within Groups & 9.742 & 57 & .171 & & \\
Total & 15.833 & 59 & & & \\
\hline
\end{tabular}

Table 4

Scheffe Post Hoc for ANOVA

\begin{tabular}{llccccc}
\hline & & Mean Difference & Std. Error & Sig. & \multicolumn{2}{c}{ 95\% Confidence Interval } \\
$(\mathrm{I})$ Groups & $(\mathrm{J})$ Groups & $(\mathrm{I}-\mathrm{J})$ & & & Lower Bound & Upper Bound \\
\hline High Skilleds & Less Skilleds & -.10000 & .15096 & .804 & -.4794 & .2794 \\
& Control Group & $.58333^{*}$ & .13073 & .000 & .2547 & .9119 \\
Less Skilleds & High Skilleds & .10000 & .15096 & .804 & -.2794 & .4794 \\
& Control Group & $.68333^{*}$ & .13073 & .000 & .3547 & 1.0119 \\
Control Group & High Skilleds & $-.58333^{*}$ & .13073 & .000 & -.9119 & -.2547 \\
& Less Skilleds & $-.68333^{*}$ & .13073 & .000 & -1.0119 & -.3547 \\
\hline
\end{tabular}

Note. ${ }^{*}$. The mean difference is significant at the 0.05 level

According to table 4, the Control group was outperformed by the other groups (HSG \& LSG). The results show that there was no significant difference between High Skilled and Less Skilled learners ( $p$ : 0.804). This indicates that the Less Skilled Group which was outperformed by both CG and HSG on the pretest managed to make a significant improvement after the treatment. However, the LS group did not do significantly better than the HS group (mean difference $=.10000$, p: 0.804), but managed to fill in the gap compared to the pretest. Both HS and Less skilled learners performed significantly different from the Control Croup at the probability level of 0.05. As it can be seen in Table 4, the results of the Less Skilled group on the posttest were significantly better than the Control Group ( mean difference $=.68333, p$ : 0.000). Moreover, HS group also outperformed CG with the mean difference of .58333 and $p$ value of 0.000 respectively.

\section{Discussion and Conclusion}

The current study looked in to the effects of Meta-cognitive strategy instruction on improving listening comprehension ability and its relationship with developing some independent language learners. The first research question posed in the study concerned the effects of meta-cognitive strategy instruction on the development of listening comprehension ability of EFL learners. The results of the study, according to the performance of the participants on the posttest, favored the treatment groups being taught via the pedagogical cycle proposed by Vandergrift (2003). The findings lend support to the idea that trying to concentrate on the process of listening comprehension rather than merely testing it (Vandergrift \& Goh, 2012) can prove helpful and result in a better listening comprehension ability by learners (White, 2006).

The findings also address the concern of the need for more pieces of research to be run on the effectiveness of metacgnitive approach (Berne, 2004). It can be argued that with the help of such pedagogical cycle of teaching listening, we may be able to train more independent language learners who can take the responsibility of their own learning process and turn into some independent language learners.

Focusing on the ability of learners to orchestrate the use of a set of strategies rather than singling out one specific strategy and teaching it (Vandergrift et al., 2010) is what makes the results of the present study different from others (e.g., Thompson \& Rubin, 1996; Mendelsohn, 2006). In the literature, a huge part of strategy instruction background supports concentrating on and teaching one strategy at a time. However, the present 
study tried to address this problem and train the students to manage the use of different strategies in different situation, focusing on the process of listening rather than on its product. Listeners were involved in some activities which were very similar to a real-life one, and that they had one goal in mind, understanding what is being said as much as they could. When the learners are instructed to listen for specific pieces of information, and are given enough opportunities to listen selectively and monitor their understanding, they can build up the ability to gain implicit knowledge of a second language listening, and turn into independent language learners (Vandergrift \& Tafaghodtari, 2010).

The findings are also congruent with Graham and Macaro (2008), (Goh, 2008) who found a positive effect in using meta-cognitive strategies. In the same vein, the studies conducted by Vandergrift $(2002,2003)$ favored the application of meta-cognitive strategy instruction. However, the findings are contrary to Ozeki' (2000) and Cross (2009). In these studies no significant relationship in the analysis of data was found to favor metacognitve instruction.

Based on the analysis of data for the second research question that taped into the possible differences between the Less and High skilled learners after receiving the treatment, the result indicated that the Less skilled learners managed to gain better outcomes compared to the other groups. The Less skilled learners had the poorest performance compared to the High skilled learners and the Control Group participants on the pretest; whereas. However, the Less skilled learners filled in the gap on the posttest by achieving a better mean score compared to the High skilled learners (but not significantly better).

The Less skilled learners also outperformed the Control Group. Generally, less skilled learners had the most noticeable improvement in comparison with other groups. This can indicate that teaching listening comprehension via a meta-cognitive approach can result in better language learners who will learn to orchestrate their listening comprehension process better (Goh, 2000). In was also noted that while the treatment is effective, it can be far more valuable for Less Skilled learners. This may be attributed to the fact that less proficient language learners face more difficulty managing their process of language learning, specifically in listening comprehension, and when they are taught how to do so, they can experience a noticeable improvement (Vandergrift \& Goh, 2012).

As Goh and Taib (2006) put it, less proficient listeners lack the capability of transferring the natural approaches of their first language listening to their second language listening context; therefore, they can benefit more from such metacognitive approaches in which they learn how to control their understanding of the flow of information by handling their strategy use (Vandergrift, 2003). Therefore, one of the possible reasons for a better performance by the Less skilled learners on the post test can be what Goh (2008) referred to as discovering these listening processes by some modeling and instruction during the treatment. This can consequently lead to better metacognitive awareness of the process of listening comprehension which enables the learners to manage their comprehension process more skillfully (Vandergrift \& Tafaghodtari, 2010; Goh, 2008), and consequently they learn how to orchestrate their strategy use. This is in line with Coskun's (2010) study which revealed some noticeable achievement for the less proficient learners.

\section{Pedagogical Implications}

\subsection{Implications for EFL Teachers}

It is hoped that the findings of the present study will encourage EFL teachers to pay closer and more consummate attention, to the concepts of listening comprehension. Considering the beneficial impacts of drawing learners' attention to more practice of listening skill, EFL teachers are expected to invest more time on the teaching of listening skill. Such an approach can be achieved through the use of a metacognitive approach.

Although teaching listening is hard to implement, and seems to be cumbersome to any teacher, it is an 
attractive teaching method for those teachers who believe in activeness of LC, and for those who prefer a more interactive approach. Teachers are expected to use a metacognitive approach in teaching listening comprehension according to learners' level of language proficiency.

\subsection{Implications for EFL Learners}

As Chastain (1998) mentioned, in order to learn to speak, students must first learn to understand the spoken language they hear, and this is where breakdowns may occur. We might observe that learners in L2 classes are somehow able to speak, but face difficulty in understanding authentic language. As Chastain indicated in his book, past experience shows that learners who go abroad are much less able to comprehend native speakers than they are to create. EFL learners are, therefore, expected to train themselves into paying full attention to this important skill in learning a second language. In the present TEFL situation in Iran, it appears that learners only hanker after speaking as their total goal to learn a second language. This being so, they often lose sight of the foundation of speaking, which is listening. Therefore, learners should make an effort to enhance their listening skill. Research has demonstrated that adults spend $40-50 \%$ of communication time on listening, and only $25-30 \%$ on speaking.

Furthermore, according to data analysis, it is suggested that the learners, both the High and Low skilled, use the instructor-directed reinforcement and activities conducted immediately after the repeated listening. These activities include the comparative analysis of the aural excerpts and their transcriptions in relation to aspects such as phonology, pronunciation, vocabulary, usage, grammar, spelling, along with further discussions of the comprehension difficulties encountered, and whenever possible, brief oral discussions on the topic of the texts where provided with the purpose of enabling the students to immediately make use of and hopefully "anchor" the new vocabulary they come across in the listening tasks.

\subsection{Implications for practice}

Theoretically, this study yields findings compatible with the claims that Metacognition plays crucial roles in the processing of language (Flavell, 1979; Hulstijn, 2003). From the pedagogical point of view, the results of this study endorse the idea claimed by Goh that the L2 "learner's voice can be very valuable to our understanding of their comprehension difficulties" (Goh, 2000, p. 56), and that learners' listening comprehension skills can largely benefit from the assistance of a metacognitive approach which makes use of text repetition, reflective listening, and process-based discussions.

\section{References:}

Anderson, N. J. (2002). The role of metacognition in second language teaching and learning. ERIC Digest, 3-4.

Berne, J. E. (2004). Listening comprehension strategies: A Review of the literature. Foreign Language Annals,

$$
\text { 37, 521-531. http://dx.doi.org/10.1111/j.1944-9720.2004.tb02419.x }
$$

Buck, G. (2001). Assessing listening. Cambridge: Cambridge University Press. http://dx.doi.org/10.1017/CBO9780511732959

Cohen, A. D., \& Macaro, E. (Eds.) (2007). Language learner strategies: Thirty years of research and practice. Oxford: Oxford University Press.

Coskun, A. (2010). The effect of meta-cognitive strategy training on the listening performance of beginner students. Novitas-ROYAL, 4(1), 35-50.

Cross, J. D. (2009b). The development of metacognition of L2 listening in joint activity. Unpublished doctoral dissertation, University of Melbourne, Australia.

DeKeyser, R. (Ed.) (2007). Practice in a second language: Perspectives from applied linguistics and cognitive psychology. Cambridge: Cambridge University Press.

Field, J. (1998). Skills and strategies: Toward a new methodology of listening. ELT, 52, 110-118. http://dx.doi.org/10.1093/elt/52.2.110 
Latifi, M., Tavakoli, M., \& Dabaghi, A.

Flavell, J. H. (1976). Metacognitive aspects of problem solving. In L. B. Resnick (Ed.), The nature of intelligence (pp. 231-235). Hillsdale, NJ: Erlbaum.

Flavell, J. H. (1979). Metacognition and cognitive monitoring: A new area of cognitive-developmental inquiry. American Psychologist, 34, 906-911. http://dx.doi.org/10.1037/0003-066X.34.10.906

Goh, C. (2000). A cognitive perspective on language learners' listening comprehension problems. System, 28, 55-75. http://dx.doi.org/10.1016/S0346-251X(99)00060-3

Goh, C. (2008). Metacognitive instruction for second language listening development: Theory, practice and research implications. RELC Journal, 39, 188-213. http://dx.doi.org/10.1177/0033688208092184

Goh, C., \& Taib, Y. (2006). Meta-cognitive instruction in listening for young learners. ELT Journal, 60, $222-232$. http://dx.doi.org/10.1093/elt/ccl002

Goh, C., \& Yusnita, T. (2006). Metacognitive instruction in listening for young learners. ELT Journal, 60(3), 222-232. http://dx.doi.org/10.1093/elt/ccl002

Grabe, W. (2009). Reading in a second language: Moving from theory to practice. New York: Cambridge University Press.

Graham, S. (2006). Listening comprehension: The learners' perspective. System, 34, 165-182. http://dx.doi.org/10.1016/j.system.2005.11.001

Graham, S., \& Macaro, E. (2008). Strategy instruction in Listening for lower intermediate learners of French. Language learning, 58(4), 747- 783. http://dx.doi.org/10.1111/j.1467-9922.2008.00478.x

Liu, X. L., \& Goh, C. (2006). Improving second language listening: Awareness and involvement. In T.S.C Farrell (Ed.), Language Teaching Research in Asia (pp. 91-106). Alexandria: TESOL International.

McGruddy, R. (1998). The effect of listening comprehension strategy training with advanced level ESL students. Dissertation Abstracts International, 59, 4416-4425.

Mareschal, C. (2007). Student perceptions of a self-regulatory approach to second language listening comprehension development. Unpublished doctoral dissertation, University of Ottawa, Canada.

Mendelsohn, D. (1994). Learning to listen: A strategy-based approach for the second language learner. San Diego: Dominie Press.

Mendelsohn, D. (2006). Learning how to listen using learning strategies. In E. Uso-Juan \& A. Martinez-Flor (Eds.), Current trends in the development and teaching of the four language skills (pp. 75-89). Berlin: Mouton de Gruyter. http://dx.doi.org/10.1515/9783110197778.2.75

Nathan, P. H. (2008). Cooperative learning and metacognitive awareness in listening comprehension. Unpublished masteral dissertation, National Institute of Education, Singapore.

Omaggion, A. G. (1986). Teaching language in context: Proficient-oriented instruction. Boston: Heinle.

O’Malley, J., Chamot, A. U., \& Kupper, L. (1989). Listening comprehension strategies in second language acquisition. Applied Linguistics, 10, 418-437. http://dx.doi.org/10.1093/applin/10.4.418

Oxford, R., \& Cohen, A. D. (1992). Language learner strategies: Crucial issues of concept and classification. Applied Language Learning, 3, 1-35.

Oxford, R. (2011). Self-regulation update on L2 listening. Language Teaching, 21, 205-211.

Ozeki, N. (2000). Listening strategy instruction for female EFL college students in Japan. Tokyo: Macmillan Language House.

Pressley, M. (2002). Metacognition and self-regulated comprehension. In A. Farstrup \& S. Samuels (Eds.), What research has to say about reading instruction (pp. 291-309). Newark, DE: International Reading Association.

Rasouli, M., Mollakhan, K. V., \& Karbalaei, A. (2013). The effect of metacognitive listening strategy training on listening comprehension in Iranian EFL context. European Online Journal of Natural and Social Sciences, 2(1), 115-128.

Rost, M. (2001). Listening. In R. Carter \& D. Nunan (Eds.), The Cambridge guide to teaching English to speakers of other languages (pp. 7-13). UK: Cambridge University Press. http://dx.doi.org/10.1017/CBO9780511667206.002

Rost, M. (2002). Teaching and researching listening. London: Longman.

Schmidt-Rinehart, B. (1994). The effects of topic familiarity on second language listening comprehension. 
The effect of metacognitive instruction on improving listening comprehension ability

Modern Language Journal, 78, 179-189. http://dx.doi.org/10.1111/j.1540-4781.1994.tb02030.x

Seo, K. (2002). The effect of visuals on listening comprehension: A study of Japanese learners' listening strategies. International Journal of Listening, 15, 57-81. http://dx.doi.org/10.1080/10904018.2002.10499049

Thompson, I., \& Rubin, J. (1996). Can strategy instruction improve listening comprehension? Foreign Language Annals, 2, 331-342. http://dx.doi.org/10.1111/j.1944-9720.1996.tb01246.x

Vaez Dalili, M., \& Tavakoli, M. (2013). A comparative analysis of reading strategies across ESP students of humanities and engineering. International Journal of Research Studies in Language Learning, 2(5), 63-78. http://dx.doi.org/10.5861/ijrsll.2013.257

Vandergrift, L. (1997). The strategies of second language (French) listeners: A descriptive study. Foreign Language Annals, 30, 387-409. http://dx.doi.org/10.1111/j.1944-9720.1997.tb02362.x

Vandergrift, L. (2002). It was nice to see that our predictions were right. Developing meta-cognition in L2 listening comprehension. Canadian Modern Language Review, 58, 555-575. http://dx.doi.org/10.3138/cmlr.58.4.555

Vandergrift, L. (2003). Orchestrating strategy use: Toward a model of the skilled second language listener. Language Learning, 53, 463-496. http://dx.doi.org/10.1111/1467-9922.00232

Vandergrift, L. (2004). Learning to listen or listening to learn. Annual Review of Applied Linguistics, 24, 3-25. http://dx.doi.org/10.1017/S0267190504000017

Vandergrift, L. (2005). Relationships among motivation orientations, metacognitive awareness and proficiency in L2 listening. Applied Linguistics, 26, 70-89. http://dx.doi.org/10.1093/applin/amh039

Vandergrift, L. (2007). Recent developments in second and foreign language listening comprehension research, Language Teaching, 60 (2), 470-497.

Vandergrift, L., \& Goh, C. (2012). Teaching and learning second language listening: Metacognition in action. New York: Routledge.

Vandergrift, L., \& Tafaghodtari, M. (2010). Teaching L2 learners how to listen does make a difference: An empirical study, .Language learning, 40, 191-210.

Wenden, A. (1999). An introduction to metacognitive knowledge and beliefs in language learning: Beyond the basics, System, 27, 435-441. http://dx.doi.org/10.1016/S0346-251X(99)00043-3

White, G. (2006). Teaching listening: Time for a change in methodology. In E. Us'o-Juan \& A. Mart'inez-Flor (Eds.), Current trends in the development and teaching of the four language skills (pp. 111-135). Berlin: Mouton de Gruyter. http://dx.doi.org/10.1515/9783110197778.2.111

Zhang, S., \& Goh, C. (2006). Strategy knowledge and perceived strategy use: Singaporean learners' awareness of listening and speaking strategies. Language Awareness, 15, 119-219. http://dx.doi.org/10.2167/la342.0

Wang, J. H., \& Li, X. (2014). Exploring meta-cognitive beliefs of postgraduates in an EFL context. International Journal of Research Studies in Language Learning, 3(1), 112-127. http://dx.doi.org/10.5861/ijrsll.2013.369 
Latifi, M., Tavakoli, M., \& Dabaghi, A. 